Journal of Agricultural Sciences
(Tarim Bilimleri Dergisi)

\title{
Effect of Combined or Separate Administration of Beta Carotene-Vitamin E and hCG on Fertility in Sheep Lambs
}

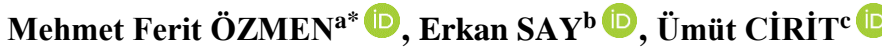 \\ ${ }^{a}$ Department of Reproduction and Artificial Insemination, Faculty of Veterinary Medicine, Dicle University, 21280, Diyarbakir, TURKEY \\ ${ }^{b}$ Eastern Mediterranean Agricultural Research Institute, Dogankent, Yuregir, Adana, TURKEY \\ ${ }^{c}$ Department of Reproduction and Artificial Insemination, Faculty of Ceyhan Veterinary Medicine, Çukurova University, 01920, Adana, TURKEY
}

ARTICLE INFO

Research Article

Corresponding Author: Mehmet Ferit ÖZMEN, E-mail: ferit-ozmen@ hotmail.com

Received: 04 May 2021 / Revised: 21 June 2021 / Accepted: 22 June 2021 / Online: 01 September 2022

\section{Cite this article}

ÖZMEN F M, SAY E, CiRiT Ü (2022). Effect of Combined or Separate Administration of Beta Carotene-Vitamin E and hCG on Fertility in Sheep Lambs. Journal of Agricultural

Sciences (Tarim Bilimleri Dergisi), 28(3):396-400. DOI: 10.15832/ankutbd.932413

\section{ABSTRACT}

This study was performed to investigate the effect of beta carotenevitamin $\mathrm{E}$ and $\mathrm{hCG}$ treatments alone or a combination of both on fertility in estrus synchronized Awassi ewe lambs. A total of 103 Awassi ewe lambs were divided into four groups before the study. Lambs were treated with a progesterone sponge for 12 days, $\mathrm{PGF}_{2 a}$ two days before sponge removal, 600 IU PMSG on sponge removal day, and 150 IU hCG on the day of mating. The control group (n: 25) did not receive any additional treatment. The Vitamin group ( $\beta$ carotene + vitamin E) (n: 26) was treated twice with vitamin combination. The first treatment was on the $7^{\text {th }}$ day before the sponge insertion and the second treatment was on the day of mating. The hCG group (n: 24) was treated with 150 IU hCG on day 12 after mating. The $\mathrm{HCG}+$ vitamin group (n: 28$)$ was treated with both $\beta$ carotene-vitamin E and hCG. Ewe lambs standing to be mounted were considered in estrus and mated. Pregnancy was determined by ultrasound the $30^{\text {th }}$ day after the mating. There were no significant differences between the control and hCG, vitamin and hCG + vitamin groups concerning estrus, conception, lambing, abortion, twinning, fecundity rate, and litter size $(\mathrm{P}>0.05)$. It was concluded that the treatments with $\beta$ carotene-vitamin $\mathrm{E}$ and hCG or both, in addition to estrus synchronization out of the breeding season in Awassi ewe lambs did not improve the investigated fertility indices.

Keywords: Beta carotene; Estrus synchronization; Ewe lambs; hCG; Progesterone

\section{Introduction}

One of the important aspects for a profitable livestock is reproductive performance (Ataç \& Kaymakçi 2021). Ewe lambs reach the reproductive ability at an average age of 8 months. However, if they are not in the breeding season, mating is delayed which results in losses for sheep farms. This negative situation can only be overcome by using estrus synchronization methods. The use of this method is limited due to the high embryonic mortality rate in pregnancies after estrus synchronization in ewe lambs out of the breeding season. In the first 3 weeks of gestation, the embryonic mortality rate varies between 30 and $40 \%$ in adult ewes, but this rate reaches 50\% in ewe lambs (Bolet 1986; Nancarrow 1994; Michels et al. 1998). It was reported that this rate is raised to 63\% in ewe lambs that mated in estrus induced by Progestagen-eCG application (Gordon 1997). 70-80\% of embryonic deaths occur between $8^{\text {th }}-16^{\text {th }}$ days after insemination (Sreenan et al. 1996). Luteal dysfunction is considered as the major cause of embryonic death (Wilmut et al.1986; Ashworth \& Bazer 1989; Nancarrow 1994). In the early stages of pregnancy, hCG or GnRH applications are considered as alternatives to reduce embryonic death rates by causing an increase in the amount of progesterone (Sreenan et al. 1996). The majority of this increase in progesterone level is mainly attributed to the formation of new corpus luteums (CL) (Mann \& Picton 1995; Beck et al. 1996). Increases in progesterone production on the $12^{\text {th }}$ day of mating or the following days may increase interferon-tau (IFN- $\tau$ ) production. (Thatcher et al. 1995). In the natural oestrus cycle, the IFN- $\tau$ increase in this period when the corpus luteum starts to regress can prevent luteolysis by preventing PGF2 $\alpha$ secretion (Bazer et al. 1998). It has been reported that administration of hCG or GnRH on the 12th day after mating improves the reproductive performance of sheep and hCG administration also increases fetal growth (Cam \& Kuran 2004; Khan et al. 2007).

Another strategy applied to reduce the embryonic mortality rate in ewes is to use some vitamins and minerals. The body levels of some vitamins and minerals [beta $(\beta)$ carotene, vitamin E, selenium, etc.] that are contained in pasture affect fertility rates. In case of deficiencies of these substances, they should be supplemented (Yokuş et al. 2006; Panousis et al. 2007). Previous studies have shown that the addition of $\beta$-carotene to animals such as cows, sheep, rabbits, and pigs improves their performance and reproductive functions (Ahlswede \& Lotthammer 1978; Brief \& Chew 1985; Kormann et al. 1989). It has been reported that 
the $\mathrm{CL}$ is rich in $\beta$-carotene and therefore $\beta$-carotene along with vitamin $\mathrm{A}$ has an important effect on the functions of luteal cells (Graves-Hoagland et al. 1989; Ceylan et al. 2007). Rapaport et al. (1998) determined that the progesterone secretion capacity of the corpus luteum is associated with the high $\beta$-carotene content in the ovaries. Because $\beta$-carotene is the only source of vitamin A in granulosa cells, it plays a role in the synthesis of steroid hormones and ovulation. In addition, there is a positive relationship between the plasma $\beta$-carotene level and the follicular fluid and luteal tissues as well as the weight of the corpus luteum (Ayaşan \& Karakozak 2010).

Vitamin E ( $\alpha$-tocopherol) protects cell membranes from oxidation by reacting with lipid radicals produced in lipid peroxidation reactions (Traber \& Atkinson 2007). This removes free radical intermediates and prevents oxidation reactions (Mohebbi-Fani et al. 2012). Oxidative damage to the ovarian epithelium due to stimulation of ovulation in sheep can be prevented by vitamin E supplementation (Murdoch \& Martinchict 2004). Various results have been reported in previous studies investigating the effects of vitamin E on fertility. Although Koyuncu \& Yerlikaya (2007) reported that vitamin E supplementation increased the incidence of estrus and fertility in sheep, some other researchers did not find the same effect (Kott et al. 1983; Kumagai \& White 1995; Gabryszuk \& Klewiec 2002; Yaprak et al. 2004).

Some studies have evaluated the effects of supplementation with various vitamins or hCG on reproduction in sheep. (Kaya et al. 2013; Köse et al. 2013; Catalano et al. 2015). However, to the best of the authors' knowledge, there is no study investigating the effects of co-administration of hCG and $\beta$-carotene + vitamin E on reproduction in ewe lambs. Therefore, this research was aimed to evaluate the effects of hCG treatment on the $12^{\text {th }}$ day after mating and $\beta$-carotene + vitamin E treatment, which was applied twice, or co-administration of these two treatment strategies in estrus synchronized ewe lambs out of the breeding season.

\section{Material and Methods}

This study was approved by Dicle University, Animal Local Ethics Committe (DÜ-HADYEK; 25249). The experiment was conducted on a commercial sheep farm in the period from the second half of April to the first week of May in the southeastern part of Turkey out of the breeding season. The study was carried out on a livestock farm in Diyarbakir province. This region is situated at $37^{\circ} 55^{\prime} 01^{\prime \prime} \mathrm{N}$ latitude, and $40^{\circ} 16^{\prime} 46^{\prime \prime}$ E longitude, and at an altitude of 660 meters.

\subsection{Animals and experimental design}

A total of 103, eight months old Awassi ewe lambs were allocated into four groups. Ewe lambs were selected randomly. They grazed on natural pasture all day and water were offered ad libitum. All ewe lambs were synchronized for estrus using progesterone-containing vaginal sponges (20 mg flugeston acetate, Chronogest CR, Intervet) for 12 days. Two days before sponge removal, prostaglandin F2 alpha (PGF2 $\alpha, 250 \mathrm{mcg}$, Estrumate, Intervet) was injected via the i.m. route. On the day of sponge removal, $600 \mathrm{IU}$ equine chorionic gonadotropin (eCG, i.m., Chronogest, Intervet) and then on the mating day $150 \mathrm{IU}$ human chorionic gonadotropin (hCG, i.m., Chorulon, Intervet) were applied via i.m. rote. No additional treatment was applied to the lambs in the control group $(n=25)$. The lambs in the vitamin group $(n=26)$ received Beta $(\beta)$ carotene + vitamin $E(0.5$ $\mathrm{ml} / 10 \mathrm{~kg}$, i.m. Ovostim, Provet) twice, one week before sponge application and on the day of mating. The hCG group of lambs $(n=24)$ was injected hCG (150 IU, i.m.) on day 12 after mating. The lambs in the hCG + vitamin group (n: 28) were treated with both hCG and $\beta$-carotene + vitamin E.

Estrus was determined by fertile rams (3-5 old) for 4 hours in the morning and evening for 4 days from the day of sponge removal. The lambs in oestrus were mated with fertile rams (lambs to ram ratio 10:1). Pregnancy was determined with the help of an ultrasound on the $30^{\text {th }}$ day after the mating.

\subsection{Statistical analysis}

The data were analyzed using the SPPS (Statistical Package for the Social Sciences) /PC program (Version 10.0; SPPS, Chicago, IL, USA). Results were expressed as percentages and comparisons among groups were evaluated using the Chi-Square test. The significance level was accepted as $\mathrm{P}<0.05$.

\section{Results}

The fertility results of the ewe lambs in the control and treatment groups are given in Table 1. Pregnancy, lambing and fecundity rates of hCG and hCG + vitamin groups were numerically (but not statistically) higher than the control group. Unexpectedly, the multiple births rate of the control group was numerically higher than all of the other groups. However, estrus, pregnancy, lambing, abortion, twining, multiple births and fecundity rates, and litter size were found to be similar statistically in all groups $(\mathrm{P}>0.05)$. 
Table 1- Comparison of fertility results among groups

\begin{tabular}{|l|l|l|l|l|}
\hline Groups & $\begin{array}{l}\text { Control } \\
\text { n: } 25\end{array}$ & $\begin{array}{l}\text { hCG } \\
\text { n:24 }\end{array}$ & $\begin{array}{l}\text { Vitamin } \\
(\beta-\text { Carotene } \\
\text { Vitamin E) } \\
\text { n: } 26\end{array}$ & $\begin{array}{l}\text { hCG + Vitamin } \\
\text { n: } 28\end{array}$ \\
\hline Estrus rate $(\%)$ & $96.0(24 / 25)$ & $100.0(24 / 24)$ & $100.0(26 / 26)$ & $96.4(27 / 28)$ \\
\hline Pregnancy rate ${ }^{1}(\%)$ & $62.5(15 / 24)$ & $79.2(19 / 24)$ & $69.2(18 / 26)$ & $77.8(21 / 27)$ \\
\hline Lambing rate $(\%)$ & $58.3(14 / 24)$ & $75.0(18 / 24)$ & $65.4(17 / 26)$ & $74.1(20 / 27)$ \\
\hline Abortion rate ${ }^{3}(\%)$ & $6.7(1 / 15)$ & $5.3(1 / 19)$ & $5.6(1 / 18)$ & $4.8(1 / 21)$ \\
\hline Multiple births rate $(\%)$ & $35.7(5 / 14)$ & $27.8(5 / 18)$ & $29.4(5 / 17)$ & $25.0(5 / 20)$ \\
\hline Fecundity rate $(\%)$ & $79.2(19 / 24)$ & $95.8(23 / 24)$ & $84.6(22 / 26)$ & $92.6(25 / 27)$ \\
\hline Litter size $^{5}(\%)$ & $135.7(19 / 14)$ & $127.8(23 / 18)$ & $129.4(22 / 17)$ & $125.0(25 / 20)$ \\
\hline
\end{tabular}

\begin{abstract}
${ }^{1}$ : Number of pregnant ewe lambs /all ewe lambs mated; ${ }^{2}:$ Number of ewe lambs lambing/all ewe lambs mated; ${ }^{3}$ : Number of ewe lambs aborted / number of ewe lambs pregnant; ${ }^{4}$ : Number of ewe lambs giving twin births/number of ewe lambs lambing; ${ }^{5}$. Number of lambs born/ number of ewe lambs mated; ${ }^{6}$ : At the birth number of lambs born/ number of ewes lambed
\end{abstract}

\title{
4. Discussion
}

It has been suggested that GnRH or hCG administration on day 10, 11, 12 or 13 post-mating improves plasma progesterone (P4) concentrations (Cam et al. 2002), early embryonic survival (Beck et al. 1994), pregnancy rate (McMillan et al. 1986), and litter size (Cam et al. 2002) in sheep. On the other hand, in several studies, it is noted that GnRH-treated sheep have consistently lower plasma P4 concentrations when compared to hCG-treated sheep (Ishida et al. 1999; Khan et al. 2007; Fernandez et al. 2018). Fernandez et al. (2018) have reported that hCG has a double effect on P4 concentrations, as it both stimulates the development of the original CL, which directly affects the LH receptors in the ovary and induces the formation of accessory CL. The hCG has a longer half-life than GnRH (Cole 2012; Fernandez et al. 2018) and it has a 3-30 fold higher binding affinity compared to LH induced by GnRH treatment (Hunter et al. 1986, 1988).

It has been reported that hCG injections administered in the early embryonic period positively affect interferon tau (Nephew et al. 1994) and/or progesterone synthesis (Khan et al. 2007; Fernandez et al. 2018; Mehri et al. 2018). The hCG stimulates blastocyst expansion and larger blastocysts release more interferon tau (Nephew et al. 1994), which results in a reduction in the number of estradiol and oxytocin receptors and inhibits or delays the luteolytic mechanism by suppressing PGF Pecretion $_{2 \alpha}$ Khan et al. 2007). Several researchers applied different doses of hCG in various ways to the synchronized ewe lambs and they reported different effects on fertility. Khan et al. (2007), who investigated the effects of hCG and GnRH applied to the ewes and ewe lambs on day 12 postmating, found that hCG or GnRH treatments can increase ovarian function, conceptus growth, and placental attachment in ewes but these improvements were less intense in ewe lambs. In another study, Khan et al. (2009) injected 200 IU hCG to estrus synchronized ewe lambs on day 12 after the mating. These authors reported that hCG treatment did not affect improving the reproductive performance of cyclic ewe lambs and ewes induced for reproduction in late anoestrus. Catalano et al. (2015) applied $300 \mathrm{IU}$ hCG on the $12^{\text {th }}$ day after mating to 8 -month-old Corridella ewe lambs synchronized with P4 containing sponges and PMSG applications out of the season. They reported no improvement in pregnancy rate or fetal weight, but hCG treatment increased plasma progesterone concentration and multiple ovulation. These authors also reported that the percentage of ewe lambs showing multiple ovulation was higher in the hCG-300 group than the control group (77.8\% vs 20.0\%; P <0.05). In the present study, although pregnancy, lambing and fecundity rates in hCG group of ewe lambs were numerically higher than the control group, these differences were not statistically significant.

It has been reported that $\beta$-carotene deficiency in feed adversely affects, either directly or indirectly, reproductive parameters such as estrus, conception, and pregnancy by changing ovary functions and intrauterine environment (Arıkan \& Muğlalı 1999; Kaçar et al. 2008). Özpınar et al. (1994) reported that $\beta$-carotene injection at 20-day intervals increased the pregnancy rate, offspring yield and twinning rate at the first insemination in ewes. Salem et al. (2015) reported that injection of $\beta$-carotene to Farafra ewe lambs every 15 days for 4 months before puberty increased the concentration of estradiol-17 $\beta$ and vitamin $A$, and lambs in this group showed more oestrus $(\mathrm{P}<0.05)$. In the present study, pregnancy, lambing and fecundity rates of $\beta$-carotene and vitamin E treated ewe lambs were found to be numerically higher than those of the control group, but these differences were not statistically significant. The reason for the lack of difference in the present study may be due to the period in which the study was conducted. Ewe lambs probably consumed plenty of green grass for 2-3 months before the study, and therefore may receive a sufficient amount of vitamins and minerals from pasture. This assumption was supported by the results of the study conducted by Beytut et al. (2005), who determined the levels of vitamins $A$ and $E$ as well as $\beta$-carotene levels of meadow-pasture grasses and feed substances in Kars province and its surroundings and reported the highest blood plasma $\beta$-carotene levels in spring and 
summer seasons. Moreover, Afshari et al. (2008) also reported that vitamin A and $\beta$-carotene levels were significantly lower in Gezel sheep in Iran during the winter compared to the summer season. Further detailed studies are needed to determine the effects of $\beta$-carotene-vitamin $\mathrm{E}$ on reproduction in ewe lambs in periods when green grass is absent or scarce.

In this study, the multiple births rate of the control group was numerically higher than those of all the other groups. This was not an expected result, although the differences were not found to be statistically significant. The results of our study did not support the hypothesis that co-administration of beta carotene + vitamin E and hCG can affect fertility positively in ewe lambs.

\section{Conclusions}

As it was concluded from the present study, administration of either $\beta$-carotene-vitamin $\mathrm{E}, \mathrm{hCG}$, or both, in addition to the estrus synchronization protocol out of the breeding season, did not significantly affect the reproductive performance in Awassi ewe lambs. For all that, in the field conditions, treating ewe lambs with hCG 12 days after estrus-synchronized matings may provide an economic contribution by increasing the pregnancy, lambing and fecundity rates numerically.

\section{References}

Afshari G, Hasanpoor A, Hagpanah H \& Amoughll-Tabrizi A (2008). Seasonal variation of vitamin A and $\beta$-carotene levels in Ghezel Sheep. Turkish Journal of Veterinary and Animal Sciences 32(2): 127-129

Ahlswede L \& Lotthammer K H (1978). Untersuchungen über eine spezifische, Vitamin A- unabhängige Wirkung des $\beta$-Carotins auf die Fertilität des Rindes: 5. Mitteilung: Organuntersuchnungen (Ovarien, Corpora lutea, Leber, Fettgewebe, Uterussekret, Nebennieren) Gewichts und Gehaltsbestimmungen. Deutsche Tierärztliche Wochenschr 85: 7-12 (in German language)

Arıkan S \& Muğlalı Ö H (1999). Effect of $\beta$-carotene on reproductive functions of some farm animals (In Turkish). Livestock Studies 39(2): 87-94

Ashworth C J \& Bazer F W (1989). Changes in ovine conceptus and endometrial function following asynchronous embryo transfer or administration of progesterone. Biology of Reproduction 40(2): 425-433. DOI: 10.1095/biolreprod40.2.425

Ataç F E \& Kaymakçi M (2021). Reproductive characteristics of chios ram lambs during the first year of life in rural farm conditions. Journal of Agricultural Sciences 27(1): 98-105. DOI: 10.15832/ankutbd.544225

Ayaşan T \& Karakozak E (2010). Use of $\beta$-carotene in animal nutrition and its effects (In Turkish). Kafkas Universitesi Veteriner Fakultesi Dergisi 16.4: 697-705

Bazer F W, Ott T L \& Spencer T E (1998). Maternal recognition of pregnancy: comparative aspects a review. Trophoplast Research 12: 375386. DOI: $10.1016 / \mathrm{S} 0143-4004(98) 80055-6$

Beck N F G, Peters A R \& Williams S P (1994). The effect of GnRH agonist (buserelin) treatment on day 12 post mating on the reproductive performance of ewes. Animal Science 58(2): 243-247. DOI: 10.1017/S1357729800042557

Beck N F, Jones M, Davies B, Mann G E \& Peters A R (1996). The effect of GnRH analogue (buserelin) treatment on day 12 post mating on ovarian structure and plasma progesterone and oestradiol concentration in ewes. Animal Science 63(3): 407-412. DOI: $10.1017 /$ S1357729800015290

Beytut E, Kamiloğlu N N, Gökçe G \& Beytut E (2005). Season variation of vitamin A, E and beta carotene levels in plasma of sheeps and meadow hay in the region of Kars and its surrounds (In Turkish). Kafkas Universitesi Veteriner Fakultesi Dergisi 11(1): 17-24

Bolet G (1986). Timing and extent of embryonic mortality in pigs, sheep and goats: genetic variability. In: Sreenan, J.M., Diskin, M.G. (Eds.), Embryonic Mortality in Farm Animals. Martinus Nijhoff, Hague

Brief S \& Chew B P (1985). Effects of vitamin A and $\beta$-carotene on reproductive performance in gilts. Journal of Animal Science 60(4): 9981004. DOI: $10.2527 /$ jas1985.604998x

Cam M A \& Kuran M (2004). Effects of a single injection of hCG or GnRH agonist on day 12 post mating on fetal growth and reproductive performance of sheep. Animal Reproduction Science 80(1-2): 81-90. DOI: 10.1016/S0378-4320(03)00158-1

Cam M A, Kuran M, Yildiz S \& Selcuk E (2002). Fetal growth and reproductive performance in ewes administered GnRH agonist on day 12 post-mating. Animal Reproduction Science 72(1-2): 73-82. DOI: 10.1016/S0378-4320(02)00071-4

Catalano M T, González C, Williams S, Videla D I \& Callejas S (2015). Reproductive performance of ewe lambs in non-breeding season exposed to hCG at day 12 post mating. Small Ruminant Research 124: 63-67. DOI: 10.1016/j.smallrumres.2014.12.014

Ceylan A, Serin İ, Akşit H, Seyrek K \& Gökbulu T C (2007). Investigation of vitamins A, E, beta-carotene, cholesterol and triglyceride concentrations in dairy cows with repeat breeder and anestrus (In Turkish). Kafkas Universitesi Veteriner Fakultesi Dergisi 13(2): 143147. DOI: $10.9775 / \mathrm{kvdf} .2007 .23-\mathrm{A}$

Cole L A (2012). hCG, the wonder of today's science. Reproductive Biology and Endocrinology 10(1): 1-18

Fernandez J, Bruno-Galarraga M M, Soto A T, de la Sota R L, Cueto M I, Lacau I M \& Gibbons A E (2018). Hormonal therapeutic strategy on the induction of accessory corpora lutea in relation to follicle size and on the increase of progesterone in sheep. Theriogenology 105: 184-188. DOI: 10.1016/j.theriogenology.2017.09.020

Gabryszuk M \& Klewiec J (2002). Effect of injecting 2-and 3-year-old ewes with selenium and selenium-vitamin-E on reproduction and rearing of lambs. Small Ruminant Research 43(2): 127-132. DOI: 10.1016/S0921-4488(02)00005-6

Gordon I R (1997). Controlled reproduction in sheep and goats. Cab. International. (2) Ireland, 450

Graves-Hoagland R L, Hoagland T A \& Woody C O (1989). Relationship of plasma $\beta$-carotene and vitamin A to postpartum cattle. Journal of Dairy Science 72(7): 1854-1858. DOI: 10.3168/jds.S0022-0302(89)79303-6

Hunter M G, Southee J A \& Lamming G E (1988). Function of abnormal corpora lutea in vitro after GnRH induced ovulation in the anoestrous ewe. Journal of Reproduction and Fertility 84: 139-148. DOI: 10.1530/jrf.0.0840139

Hunter M G, Southee J A, Mc Leod B J \& Haresign W (1986). Progesterone treatment has a direct effect on GnRH induced preovulatory follicles to determine their ability to develop into normal corpora lutea in anoestrous ewes. Journal of Reproduction and Fertility 76: 349 363. DOI: $10.1530 /$ jrf.0.0760349 
Ishida N, Okada M, Sebata K, Minato M \& Fukui Y (1999). Effects of GnRH and hCG treatment for enhancing corpus luteum function to increase lambing rate of ewes artificially inseminated during the non-breeding season. Journal of Reproduction and Development 45: 7379. DOI: $10.1262 /$ jrd.45.73

Kaçar C, Kamiloğlu N N, Gürbulak K, Pancarc1 Ş M, Güngör Ö, Guevenc K \& Saban E (2008). The Effect of administration of testosterone antibody, $\beta$-carotene and vitamin E on multiple pregnancy and MDA (Malondialdehyde) in Tuj breed sheep in non-breeding season (In Turkish). Kafkas Universitesi Veteriner Fakultesi Dergisi 14(1): 51-56. DOI: 10.9775/kvfd.2008.03-A

Kaya S, Kaçar C, Kaya D \& Aslan S (2013). The effectiveness of supplemental administration of progesterone with GnRH, hCG and PGF2 $\alpha$ on the fertility of Tuj sheep during the non-breeding season. Small Ruminant Research 113(2-3): 365-370. DOI: 10.1016/j.smallrumres.2013.03.018

Khan T H, Beck N F \& Khalid M (2007). The effects of GnRH analogue (buserelin) or hCG (Chorulon) on Day 12 of pregnancy on ovarian function, plasma hormone concentrations, conceptus growth and placentation in ewes and ewe lambs. Animal Reproduction Science 102(34): 247-257. DOI: 10.1016/j.anireprosci.2006.11.007

Khan T H, Beck N F G \& Khalid M (2009). The effect of hCG treatment on Day 12 post-mating on ovarian function and reproductive performance of ewes and ewe lambs. Animal Reproduction Science 116(1-2): 162-168. DOI: 10.1016/j.anireprosci.2009.01.010

Kormann A W, Riss G \& Weiser H (1989). Improved reproductive performance of rabbit does supplemented with dietary beta-carotene. The Journal of Applied Rabbit Research 12: 15-21

Kott R W, Ruttle J L \& Southward G M (1983). Effects of vitamin E and selenium injections on reproduction and preweaning lamb survival in ewes consuming diets marginally deficient in selenium. Journal of Animal Science 57(3): 331-337. DOI: 10.2527/jas1983.573553x

Koyuncu M \& Yerlikaya H (2007). Effect of selenium-vitamin E injections of ewes on reproduction and growth of their lambs. South African Journal of Animal Science 37(4): 233-236. DOI: 10.4314/sajas.v37i4.4095

Köse M, Kırbaş M, Dursun Ş \& Bayril T (2013). The effect of injections of $\beta$-carotene or vitamin E + selenium on fertility in ewes in anestrus season (In Turkish). Van Veterinary Journal 24(2): 83-86

Kumagai H \& White C L (1995). The effect of supplementary minerals, retinol and $\alpha$-tocopherol on the vitamin status and productivity of pregnant merino ewes. Australian Journal of Agricultural Research 46(6): 1159-1174. DOI: 10.1071/AR9951159

Mann G E \& Picton H M (1995). Ovarian and uterine effects of a single buserelin injection on day 12 of the oestrous cycle in the cow. Journal of Reproduction and Fertility Abstr. Ser. 15:23

McMillan W H, Knight T W \& Macmillan K L (1986). Effects of gonadotrophin releasing hormone (buserelin) on sheep fertility. Proceedings of the New Zealand Society of Animal Production 46: 161-163

Mehri R, Rostami B, Masoumi R \& Shahir M H (2018). Effect of injection of GnRH and hCG on day 5 post mating on maternal P4 concentration and reproductive performance in Afshari ewes. Journal of Comparative Pathobiology 14: 2363-2370

Michels H, Vanmontfort D \& Dewil E (1998). Decuypere E. genetic variation of prenatal survival in relation to ovulation rate in sheep: a review. Small Ruminant Research 29(2): 129-142. DOI: 10.1016/S0921-4488(97)00126-0

Mohebbi-Fani M, Mirzaei A, Nazifi S \& Shabbooie Z (2012). Changes of vitamins A, E, and C and lipid peroxidation status of breeding and pregnant sheep during dry seasons on medium-to-low quality forages. Tropical Animal Health and Production 44: 259-265

Murdoch W J \& Martinchict J F (2004). Oxidative damage to DNA of ovarian surface epithelial cells affected by ovulation: carcinogenic implication and chemoprevention. Experimental Biology and Medicine 229(6): 546-552. DOI: 10.1177/153537020422900613

Nancarrow C D (1994). Embryonic mortality in the ewe and doe. In: Zavy, M.T., Geisart RD (Eds.), Embryonic Mortality in Domestic Species, London, pp. 79-97

Nephew K P, Cardenas H, McClure K E, Ott T L \& Bazer F (1994). Effects of administration of human chorionic gonadotropin or progesterone before maternal recognition of pregnancy on blastocyst development and pregnancy in sheep. Journal of Animal Science 72: 453-458. DOI: $10.2527 / 1994.722453 x$

Özpınar H, Şenel H S, Özpınar A \& Çekgül E (1994). Pharmacokinetics of intramuscular administered $\beta$-carotene and its effects on reproduction in sheep. Wiener Tierärztliche Monatsschrift 82: 229-231

Panousis N, Giadinis N, Roubies N, Fytianou A, Kalaitzakis E, Pourliotis K, Polizopoulou Z \& Karatzias H (2007). Selenium, vitamin E and vitamin A status in dairy sheep reared under different feeding systems in Greece. Journal of Veterinary Medicine Series A 54(3): 123-127. DOI: 10.1111/j.1439-0442.2007.00907.x

Rapaport R, Sklan D, Wolfenson D, Shaham-Albalancy A \& Hanukoglu I (1998). Antioxidant capacity is correlated with steroidogenic status of the corpus luteum during the bovine estrous cycle. Biochimica et Biophysica Acta 1380(1): 133-140. DOI: 10.1016/S03044165(97)00136-0

Salem A A, El-Shahawy N A \& Soliman I A (2015). "Effect of beta-carotene injection on estrus, vitamin A and estradiol-17- $\beta$ concentrations in pubertal farafra ewe lambs. Egypt Journal Animal Production 52: 123-128

Sreenan J, Diskin M \& Dunne L (1996). Embryonic mortality the majorcause of reproductive wastage in cattle. In: Proceedings of the $47^{\text {th }}$ Annual Meeting of the European Association of Animal Production, Lillihammer, August. Páginas

Thatcher W W, Meyer M D \& Danet-Desnoyers G (1995). Maternal recognition of pregnancy. Journal of Reproduction and Fertility 49(Suppl.): 15-28

Traber M G \& Atkinson J (2007). Vitamin E, antioxidant and nothing more. Free Radical Biology and Medicine 43(1): 4-15. DOI: 10.1016/j.freeradbiomed.2007.03.024

Wilmut I, Sales D I \& Ashworth C J (1986). Maternal and embryonic factors associated with prenatal loss in mammals. Journal of Reproduction and Fertility 76(2): 851-864. DOI: 10.1530/jrf.0.0760851

Yaprak M, Emsen E, Emsen B \& Macit M (2004). The influence of vitamin E supplementation during late pregnancy on lamb mortality and ewe productivity in Awassi ewes. Journal of Animal and Veterinary Advances 3: 190-193

Yokuş B, Cakır D U, Kanay Z, Gulten T \& Uysal E (2006). Effects of seasonal and physiological variations on the serum chemistry, vitamins and thyroid hormone concentrations in sheep. Journal of Veterinary Medicine 53(6): 271-276. DOI: 10.1111/j.1439-0442.2006.00831.x

(C) 2022 by the author(s). Published by Ankara University, Faculty of Agriculture, Ankara, Turkey. This is an Open Access article distributed under the terms and conditions of the Creative Commons Attribution (CC BY) license (http://creativecommons.org/licenses/by/4.0/), which permits unrestricted use, distribution, and reproduction in any medium, provided the original work is properly cited. 